\title{
Small and medium-sized business in the system of mono-towns specializing in ferrous metallurgy
}

\author{
Kymbat Kunanbaeva ${ }^{1, *}$, Anzhela Litvinova $^{1}$, Aibol Argyngazinov ${ }^{2}$ and Elena Znamenskaya $^{3}$ \\ ${ }^{1}$ Financial University under the Government of the Russian Federation, 49, Leningradsky Prospekt, \\ 125993, Moscow, Russia \\ ${ }^{2}$ Peoples' Friendship University of Russia, 6, Miklukho-Maklaya str., 117198, Moscow, Russia \\ ${ }^{3}$ Moscow State University of Civil Engineering, 26, Yaroslavskoe Shosse, 129337, Moscow, Russia
}

\begin{abstract}
The article presents the study of functioning of small and medium-sized businesses in Russian mono-towns with the city-forming organizations of ferrous metallurgy, as well as the evaluation of prospects of development of small and medium-sized businesses in mono-towns specializing in ferrous metallurgy. The research also focuses on foreign experience of overcoming problems arising in mono-towns.
\end{abstract}

\section{Introduction}

In the system of mono-towns, there is a string correlation between the functioning of the city-forming organization and the socio-economic development of the municipal unit. The consequences of the crisis have changed the social life of mono-towns, owing to the narrow sector of employment of the population and limited measures of the population in case of job loss, as well as curtailment of social infrastructure and problems of functioning of cityforming organizations. Thus, according to the monitoring data, the most common crisis factors are termination of activity or a dramatic reduction in manufacturing due to unfavorable business conditions, sustained bankruptcy procedures, and low capacity utilization [1]. Moreover, in 206 mono-towns, the registered unemployment rate exceeds the national average which is $1.2 \%$ of the economically active population [2].

In order to reduce dependence on the city-forming business, diversification of the municipal economy, the key driver of which is small and medium-sized business, is initiated. When considering mono-towns, special attention should be paid to industry specificity. At the industry level, mono-towns are diverse, and the development of small and medium-sized businesses and the crisis recovery determine decisions that are based on particular characteristics of the industry.

Enterprises of ferrous metallurgy are concentrated in mono-towns and form the basis for the development of the territories of operations, by performing important social functions. Ferrous metallurgy as a leading industry of the national economy ensures the functioning of basic industries (engineering, automotive industry, construction, machine tool engineering, etc.). In modern realities, metallurgy, as well as other commodity markets, are in a crisis

* Corresponding author: kunanbaeva_kymbat@mail.ru 
situation; a decrease in world prices for metals affects the city-forming organizations specializing in ferrous metallurgy. Given the significant role of these organizations in ensuring revenues of mono-towns and employment of the population, there is a serious risk of worsening of socio-economic conditions in mono-towns specializing in ferrous metallurgy. In this regard, in the study of development prospects in the system of monotowns specializing in ferrous metallurgy, small and medium-sized business is of great importance.

\section{Materials and Methods}

Under the conditions of strong dependence on one industry, small and medium-sized business in mono-towns specializing in ferrous metallurgy is mainly aimed at the spheres of trade, personal services, the development of hotels and restaurants and real estate operations. Leadership of the trade business is justified by the simplicity of business operations and the high rate of turnover. Despite the fact that mono-towns specializing in ferrous metallurgy have industrial capacity in the structure of small and medium-sized businesses, the share of industrial enterprises is low.

The production of ferrous metals is characterized by a high concentration of the working-age population (the metallurgical industry employs $2.2 \%$ of the country's working population). However, there is a problem of employee displacement owing to automation and optimization of production. Therefore, the displacement of personnel of city-forming organizations might lead to an increase in unemployment, where the key tool could be the strong support for small and medium-sized businesses. The population of mono-towns specializing in ferrous metallurgy is small. Almost 2/3 of mono-towns specializing in ferrous metallurgy have a population of 30 to 100 thousand people, where there are problems of personnel training, high level of population movement. In addition, monotowns specializing in ferrous metallurgy are characterized by a high concentration of production, since the industry's enterprises were located on the territory of the country, primarily depending on the availability of raw materials.

The industry specificity of mono-towns requires an individual approach to solution of problems. More than 30 mono-towns are directly affected by the crisis in ferrous metallurgy. And, when solving this problem, it is necessary not only to support the cityforming business, but to implement anti-crisis measures that would be based on the territorial features of mono-towns and the corporate policy of metallurgical holding companies.

The distinctive feature of the formation of mono-towns specializing in ferrous metallurgy is the diversity in terms of population. There are small cities (for instance, Bakal), medium towns (for instance, Beloretsk), big towns (for instance, Magnitogorsk). Small towns specialize in carrying out single technological processes. In large cities, the factories (in Nizhny Tagil, Magnitogorsk) have a complete production cycle, which, due to the volume of production, requires the involvement of significant human resources.

Based on belonging to a certain category in accordance with the Decree [3], monotowns with metallurgical plants are demonstrated in Table 1. 
Table 1. Small and medium-sized businesses in mono-towns specializing in ferrous metallurgy.

\begin{tabular}{|c|c|c|c|c|c|}
\hline $\begin{array}{c}\text { № (The } \\
\text { number in } \\
\text { the List of } \\
\text { mono- } \\
\text { towns is } \\
\text { indicated } \\
\text { in } \\
\text { parenthese } \\
\text { s) }\end{array}$ & $\begin{array}{c}\text { Mono- } \\
\text { town } \\
\text { (town } \\
\text { populatio } \\
\text { n. } \\
\text { thousand } \\
\text { people) }\end{array}$ & $\begin{array}{l}\text { List of city-forming } \\
\text { organizations } \\
\text { (number of } \\
\text { employees. } \\
\text { thousand people) }\end{array}$ & $\begin{array}{l}\text { Number of } \\
\text { SMEs } \\
(2018)\end{array}$ & $\begin{array}{l}\text { Operating } \\
\text { structure of } \\
\text { SMEs }\end{array}$ & $\begin{array}{c}\text { State } \\
\text { program for } \\
\text { development } \\
\text { of small and } \\
\text { medium- } \\
\text { sized } \\
\text { enterprises }\end{array}$ \\
\hline \multicolumn{6}{|c|}{ Iron and steel works } \\
\hline \multicolumn{6}{|c|}{ Municipal units with the most difficult socio-economic situation } \\
\hline $1(87)$ & $\begin{array}{l}\text { Asha } \\
(30.7)\end{array}$ & $\begin{array}{l}\text { Ashinskiy metallurgi } \\
\text { cal works OJSC (4.0) }\end{array}$ & $\begin{array}{l}1560 \text { SMEs } \\
\text { (including } 3 \\
\text { medium- } \\
\text { sized } \\
\text { businesses. } \\
330 \text { small } \\
\text { businesses. } \\
1219 \\
\text { individual } \\
\text { entrepreneur } \\
\text { s. } 11 \text { farms) }\end{array}$ & $\begin{array}{l}54 \% \text { - trade. } \\
10 \% \text { - } \\
\text { manufacturing } \\
9 \% \\
\text { construction. } \\
8 \% \text { - transport } \\
\text { and } \\
\text { communication } \\
\text { s. } 4 \% \text { - housing } \\
\text { services and } \\
\text { utilities. 15\% - } \\
\text { miscellaneous }\end{array}$ & $\begin{array}{l}\text { Support and } \\
\text { development } \\
\text { of small and } \\
\text { medium-sized } \\
\text { enterprises in } \\
\text { Ashinsky } \\
\text { Municipal } \\
\text { District }\end{array}$ \\
\hline $2(28)$ & $\begin{array}{l}\text { Guryevsk } \\
(24.1)\end{array}$ & $\begin{array}{l}\text { Guryevsky } \\
\text { Metallurgical Plant } \\
\text { OJSC (1.4) }\end{array}$ & 1076 entities & $\begin{array}{l}51 \% \text { - trade. } \\
7.9 \% \text { - } \\
\text { agriculture. } 7 \% \\
- \\
\text { manufacturing. } \\
8.3 \% \text {. } \\
\text { transport and } \\
\text { communication } \\
\mathrm{s} ; \quad \text { and } \\
\text { miscellaneous }\end{array}$ & $\begin{array}{l}\text { Comprehensi } \\
\text { ve support for } \\
\text { small and } \\
\text { medium-sized } \\
\text { enterprises in } \\
\text { Guryevsky } \\
\text { Municipal } \\
\text { District }\end{array}$ \\
\hline $3(51)$ & $\begin{array}{l}\text { Chusovoy } \\
(50.4)\end{array}$ & $\begin{array}{l}\text { Chusovoy } \\
\text { Metallurgical Works } \\
\text { AO (2.7) }\end{array}$ & $\begin{array}{l}2293 \text { entities } \\
\text { (including } \\
1364 \\
\text { individual } \\
\text { entrepreneur } \\
\text { s. } 929 \text { legal } \\
\text { persons) }\end{array}$ & $\begin{array}{l}37 \% \text { - trade. } \\
6.4 \% \\
\text { construction. } \\
5 \% \\
\text { agriculture. } 6 \% \\
- \\
\text { manufacturing. } \\
\text { and } \\
\text { miscellaneous }\end{array}$ & $\begin{array}{l}\text { The } \\
\text { development } \\
\text { of small and } \\
\text { medium-sized } \\
\text { enterprises in } \\
\text { the } \\
\text { Chusovskoy } \\
\text { Municipal } \\
\text { District of } \\
\text { Perm Krai }\end{array}$ \\
\hline \multicolumn{6}{|c|}{ Municipal units with risks of worsening socio-economic situation } \\
\hline $4(223)$ & $\begin{array}{l}\text { Kamensk- } \\
\text { Uralsky } \\
(173.3)\end{array}$ & $\begin{array}{l}\text { Kamensk-Uralsky } \\
\text { Metallurgical Works } \\
\text { JSC }\end{array}$ & 5156 entities & $\begin{array}{l}41.9 \% \text { - trade. } \\
16.6 \%-\text { real } \\
\text { estate. } 5.8 \%- \\
\text { transport. } 1.6 \% \\
-\quad \text { agriculture. } \\
\text { and } \\
\text { miscellaneous }\end{array}$ & $\begin{array}{l}\text { The } \\
\text { development } \\
\text { strategy of } \\
\text { small and } \\
\text { medium-sized } \\
\text { enterprises in } \\
\text { Sverdlovsk } \\
\text { Oblast for the } \\
\text { period until } \\
2035\end{array}$ \\
\hline
\end{tabular}




\begin{tabular}{|l|l|l|l|l|l|}
\hline \multicolumn{2}{|l|}{ Municipal units with a stable socio-economic situation } \\
\hline $5(282)$ & Vyksa & Nizhny Novgorod & 2536 entities & $34.1 \%-$ trade. & Municipal \\
& $(83.8)$ & Oblast & & $30.3 \%$ program \\
& & & construction. & "Developmen \\
& & & $11.2 \%$ - & t of small and \\
& & & manufacturing. & medium-sized \\
& & & agriculture. & enterprises in \\
& & & and & district of \\
& & & miscellaneous & Vyksa" \\
\hline
\end{tabular}

Source: compiled by the author based on the data [4-8].

The study of the industry structure of small and medium-sized businesses in monotowns shows that, in Asha and Guryevsk, more than 50\% belongs to trade. However, in Guryevsk, agriculture constitutes more than 7\%, which might attract attention for the development of small and medium-sized businesses. In Vyksa, construction takes second place after trade, which is associated with the development in a mono-town specializing in ferrous metallurgy, since construction as a related industry, consumes structural materials. Furthermore, there are niches for the development of maintenance/repair services in construction for small and medium-sized businesses.

The study of normative legal documents in the field of small and medium-sized business development in these cities displays that there are program documents and, in addition, the implementation of the National project is worth noting.

In mono-towns specializing in ferrous metallurgy, there are a number of issues associated with environmental problems. Thus, the ecological situation in mono-towns specializing in ferrous metallurgy is critical, since ferrous metallurgy enterprises emit approximately 1.5 million tons of carbon dioxide per year. This reduces the appeal of potential investors and owners of small and medium-sized businesses. Moreover, this affects the health of the population, which increases the likelihood of moving of the working-age population, of young people. In this regard, young people should be motivated through the implementation of social and environmental projects.

It should also be noted that in the development of small and medium-sized businesses in the system of mono-towns specializing in ferrous metallurgy, the interaction between SMEs and the city-forming organization is particularly significant.

Forms of interaction could be implemented through the conclusion of a trilateral cooperation agreement (municipality, city-forming organization, entity of small and medium-sized business), that allows small businesses to provide post-sale services, repair, maintenance work, or to participate in certain production processes. The advantages of cooperation between the city-forming organization specializing in ferrous metallurgy and small / medium-sized businesses in the mono-town system are:

- an opportunity for small businesses to work with consumers and customers of the city-forming organization directly, however, under the trademark of a large enterprise (not a dealer network);

- access to high-technology equipment (rental of production facilities, repairs with subsequent use);

- simplification of participation in tender;

- simplification of the franchise registration procedure;

- placing orders for component parts on a variety of small manufacturing enterprises allows to concentrate the forces of a city-forming organization on more complex technological processes;

- borrowing human, intellectual resources from a small enterprise by a city-forming organization (based on the principle of outsourcing, subcontracting - in construction);

- location of workshops and other units on the territory of a small enterprise. 
The study of foreign practices in stimulating the development of small and mediumsized businesses in the system of mono-towns specializing in ferrous metallurgy allows to summarize a number of promising areas. As the experience of many foreign practices shows, the transformation from a mono to a multi-profile economy is carried out through the development of small and medium-sized businesses. The examples of the effective transformation are: the development of higher education (Ruhr, Germany); the construction of new residential buildings, as well as the development of export of small and mediumsized businesses (the UK); high social responsibility and cooperation of city-forming organizations with municipal authorities: "lifetime employment" (Kamaishi, Japan); the creation of a tourist resort area, the transformation of a mono-town into a "museum city" (Ostrava, Czech Republic), etc. [9].

\section{Results}

At the present time, many city-forming organizations are strategically important for the Russian economy and are considered to be systemic organizations, the products of which dominate global markets, which determines their development and further functioning. It should be noted that city-forming organizations operate in strong correlation with related industries, where the liaison between industries plays a particular role in stimulating small and medium-sized businesses, which implies the creation of a cluster-type city. This is considered to be the prospect for further development of small and medium-sized businesses, that is the transformation of a mono-town into a cluster-type city, meaning the formation of groups of interdependent large, medium and small enterprises and the associated institutes in a particular industry on the territory of a mono-town, which would be united by common objectives and would complement one another. The development of small and medium-sized businesses in correlation with the city-forming organization dominates in the formation of a cluster-type city.

In addition, the experience of the Republic of Kazakhstan should be noted as one of successful foreign practices. The development of small and medium-sized businesses in mono-towns of Kazakhstan indicates the successful implementation of the 2012-2020 development program of mono-towns. This program is aimed at sustainable socioeconomic development of mono-towns in the medium-term and the long-term. The main tools for implementing the sub-program "SME development" are: subsidizing interest rates on loans; developing industrial infrastructure; allocating grants for the creation of new industries; implementing affiliate programs; creating business incubators with micro-credit organizations; creating business support centers; promoting the development of entrepreneurship for the self-employed, unemployed and disadvantaged population [10]. Furthermore, the program "Business Road Map 2020", which is developed as a mechanism for implementing the State program for accelerated industrial-innovative development of the Republic of Kazakhstan is particularly worth noting in 2010-2014. This program includes entrepreneurship education, financing of small business projects and full support of the business from inception of the idea to the creation of a specific product / service. The program was actively implemented in all regions and district centers of the country, and contributed to the development of SMEs. Small business projects were aimed at developing priority sectors of the economy.

\section{Conclusions}

Thus, in the system of mono-towns specializing in ferrous metallurgy, small and mediumsized businesses can closely cooperate with other subsystems, in particular, with the city- 
forming organization or the municipal administration. The main activities of the subsystems that contribute to the development of small and medium-sized businesses are:

- promoting the innovative nature of the development of small and medium-sized businesses, for which it is reasonable to create conditions for the experience exchange with enterprises of other regions and countries, especially since the geography of real and particularly potential consumers is wider for production enterprises than for organizations in other sectors of the economy;

- arranging the selling process of used equipment by large industrial enterprises to small and medium-sized businesses;

- subsidizing enterprises' expenses for the purchase of equipment by the local budget;

- broadening opportunities for small businesses in terms of access to financial resources (soft loans, finance lease);

- by attracting financial resources from budgets of various levels in the form of financial support, as well as liaising with "SME Bank" and other organizations that are willing to finance innovative projects in the field of small business; - creating joint ventures with the investors;

- simplified access to material resources, including land resources, for small businesses. An important expansionary measure that could involve business in the production sector is the municipality's preparation of land plots equipped with the necessary communications for transferring ownership to SMEs allowing for the deferred payment;

- simplified access to energy infrastructure.

\section{References}

1. O monitoringe sotsial'no-ekonomicheskogo polozheniia monogorodov, http://government.ru/orders/22920/

2. Monogoroda: nekotorye vazhnye rezul'taty $i$ pokazateli 2015 goda, http://government.ru/info/22707/

3. Rasporiazhenie Pravitel'stva RF ot 29.07.2014 N 1398-r (red. ot 21.01.2020) http://www.consultant.ru/document/cons_doc_LAW_166540/

4. Sait goroda Asha i Ashinskogo raiona, http://gorod-asha.ru/

5. Gur'veskii gorodskoi okrug, https://gurievsk.gov39.ru/

6. Chusovskoi munitsipal'nyi okrug, http://chusrayon.ru/

7. Kamensk-Ural'skii, https://kamensk-uralskiy.ru/

8. A. Mottaeva, A. Ivashchenko, A. Ryattel, E3S Web of Conferences 164, 10038 (2020) https://doi.org/10.1051/e3sconf /202016410038

9. T.V. Uskova, L.G. Iogman, S.N. Tkachuk, A.N. Nesterov, N.Iu. Litvinova, Monogorod: upravlenie razvitiem (Vologda, ISERT RAN, 2012)

10. V. Holodkova, A. Mottaeva, T. Pokrovskaya, E3S Web of Conferences 164, 11043 (2020) https://doi.org/10.1051/e3sconf/202016411043

11. O monitoringe sotsial'no-ekonomicheskogo polozheniia monogorodov, http://government.ru/orders/22920/

12. Y.V. Morozyuk, A.V. Sharkova, I.A. Merkulina, O.N. Vasilyeva, Journal of Environmental Management and Tourism 8.3(19), 507-515 (2017)

13. K. Kunanbayeva, A. Gorovoy, A. Butyrin, MATEC 193, 05048 (2018) https://doi.org/10.1051/matecconf/201819305048 